\title{
MOTHERS' SOCIO-ECONOMIC STATUS AND HEALTH CARE FOR MATERNAL MORBIDITY: A STUDY IN URBAN DHAKA
}

\section{SANZIDA AKHTER}

\begin{abstract}
:
This paper aims at understanding how mothers' socio-economic conditions perpetuated their maternal illness conditions and low health care status. Using in-depth interview as a methodological tool the study was conducted among the mothers, who had given birth to at least one child or became pregnant at least once in the last five years preceeding the survey, in two slums and two health care facilities in Dhaka. The major findings suggests that in the urban context, where health care facilities are mostly in close proximity of the mothers, the reason for their inadequate health care for childbirth and post-partum care may lie in the socio-cultural atmosphere of the urban slum the mothers live in e.g., social network, availability of information, support network from family and neighborhood etc. as well as the 'personal characteristics' of mothers like education, age and self-esteem. Together, the social arrangements and personal characteristics may hinder mothers from being 'capable' enough to achieve the optimum 'functioning' by using their limited resources and money. And this leads to morbidity conditions during and after delivery.
\end{abstract}

\section{Keywords:}

Maternal morbidity, socio-economic condition, maternal health care, urban Dhaka, poverty

\section{Authors:}

SANZIDA AKHTER, University of Dhaka, Bangladesh, Email: sanzida209@yahoo.com

\section{Citation:}

SANZIDA AKHTER (2016). Mothers' socio-economic status and health care for maternal morbidity: a study in urban Dhaka . International Journal of Social Sciences, Vol. V(1), pp. 1-26.,

$10.20472 /$ SS.2016.5.1.001 


\section{Introduction}

Experience of motherhood is interwoven with the social, economic, cultural, familial and political contexts, which mothers live in (Oakley 1984; Rothman 1982; Winikoff 1988). So is women's maternal health care. During childbirth and post-partum period women may suffer from illness conditions and health complications which may require specialised health care in order to make a healthy pregnancy outcome. The illness condition known as maternal morbidity is "caused by, aggravated by, or associated with pregnancy or childbirth" (Reed et al. 2000, p. 3) affects a large number of women's health, particularly in the developing countries.

For every woman who dies of pregnancy-related causes, 20 or 30 others experience acute or chronic morbidity, often with permanent sequelae that can affect women's physical, mental or sexual health, productive and reproductive capability (Firoz et al. 2013 , p. 794). Filippi et al. $(2006$, p. 1,537$)$ broadly categorize the consequences of maternal death and near-miss into economic (lack of capital, no savings, debts and poverty), physical (no living child, damaged pelvic structure, anaemia, impaired functionality, infertility), social (marital disharmony, household dissolution, migration, social isolation, stigmatisation) and psychological consequences (suicide, depression). That is why, for improved maternal health, prevention of maternal morbidity and health care for maternal morbidity needs to be dealt with great attention and care. Since most maternal health programs are aimed at reducing the number of maternal deaths, the maternal morbidity aspect of maternal health has often been ignored (Lewis 2003, p. 30; Glazener et al. 1995, p. 282). Bangladesh, inspite of having MDG 5 target of reducing maternal mortality ratio (MMR) achieved, still has $76.6 \%$ deliveries of children at home. As evidenced from NIPORT et al. (2012, p. 4), which revealed that while maternal mortality during pregnancy and child delivery declined by 50\% between 2001 and 2010 , maternal mortality during the post-partum period (i.e., within 42 days after delivery) was reduced by only a third. In Bangladesh, post-partum maternal deaths now account for a higher proportion of maternal deaths, which is $73 \%$ in 2010 compared to $67 \%$ in 2001 (NIPORT et al. 2012, p. 11). Of those women suffering from maternal complications, $50 \%$ do not receive any treatment; almost all come from developing countries in Asia and Africa (Ashford 2002, p. 2). Against this backdrop, this paper discusses the socioeconomic status of mothers of the lower socio-economic households in Dhaka, the capital of Bangladesh and their maternal mornibisities and related health care status.

Health care seeking behaviour is a complex issue involving a wide range of aspects of human lives. They range from very personal traits to societal and state level policy, which interplays between need and supply of health care. The existing literature endeavours to understand the determinants of health care seeking behaviour of mothers of developing countries. Among the well documented factors that are incorporated in the most health care seeking behaviour approaches or models are: demographic, socio-cultural and economic characteristics of people and communities, most particularly income and education (Anwar et al. 2008, p. 256); enabling factors like availability, accessibility and cost of services involved; infrastructure development, transport and communication (Shaikh and Hatcher 2005, pp. 50-51); geographical 
location of the residence of treatment requiring women (Sharma, Sawangdee and Sirirassamee 2007, p. 687); perception, beliefs and attitudes towards illness and treatment; and nature and extent of illness (Goodburn, Gazi and Chowdhury 1995, p 29).

However, these complexities of maternal health care seeking behaviour have mostly focused on the context of rural areas and poverty. Moreover, the complexities of health care seeking behaviour in an urban context, where low cost maternal health care facilities are located close to most people's residences, have not been adequately addressed either (Afsana and Wahid 2013, p. 2050). That is why, in understanding socio-economic considitons and maternal morbidity this paper particularly focuses on urban poor mothers of Dhaka.

\section{Methodology}

The findings presented in this paper are drawn on in-depth interviews with the mothers who had become mothers or had become pregnant at least once in the last five years preceeding the survery. Through this interview, the accounts of experience of mothers of maternal morbidity and maternal health care are collected. The methodological principle, which this research draws upon is the experience of individuals as an authentic source of knowledge. Stacey (1994) suggested, people themselves have the best expertise in understanding and explaining their experience because they are the ones who live in the context, while constructing the experience. Thus, their account not only gives information of the experience but also renders meaning to that information, as they relate their experience with the existing context. Valuing the experience of mothers in such a way can contribute to producing knowledge of childbirth and maternal health care from a different perspective, where the mothers' voices are heard, and their experiences are reflected upon and accounted for.

\section{1: Study Area}

Dhaka is the obvious choice of study for a research project on urban women as it is a pre-eminent city of Bangladesh. Within this sprawling metropolis the poor mainly live in informal settlements (slums), scattered throughout the city. The structure of housing, where low income people live, is generally of poor quality with very low level basic infrastructure. Human Development Research Centre (2011, p. 4) mentioned that only $25 \%$ of the population of Dhaka is served by sewer network. The sanitary conditions in urban slums are therefore very deplorable, with only $8 \%$ to $12 \%$ having hygienic latrines. In the late 2000s, sanitation coverage reached only $8.5 \%$ of Dhaka slums (MICS 2009, mentioned in Human Development Research Centre 2011, p. 4).

Structural disadvantages along with a low level of education and health services make the poor people of the urban Dhaka more vulnerable than the richer people. The adverse surroundings of low income settlements, coupled with a high density population, gives rise to a myriad of social, health-related and environmental problems 
(Siddiqui et al. 2000; Hossain 2008). The existing health care centres in the city have failed to cope with the rapid growth of the city's population (Siddiqui et al. 2000). Kelly (2012) reported that hospitals are already unable to meet the growing demand of treatment and services. NIPORT et al. (2008, p. 213) in their Bangladesh Urban Health Survey 2006 reported that $48.8 \%$ of urban slum area of Bangladesh has no access to health programs or service centres in their surroundings. While there is a recent proliferation of private hospitals and clinics in Dhaka, according to Siddiqui et al. (2000) those health facilities provide services only to the people from upper socio-economic households. For the urban poor, receiving health services from the limited available health resources is challenging due to many seen and unseen barriers, including unofficial user fees, malpractice of power by the authority, and lack of awareness (Begum, Yeasmin and Seem 2010, p. 44).

In selecting households in Dhaka first an informal settlement (popularly called Slum) in the Dhaka City Corporation (DCC) area was chosen. Having no list of slums in DCC available, the slum was selected based on two simple criteria:

- Overall low income level and low level of development intervention in this area

- Safe and secure for my research assistant and me.

In doing so, the DCC was divided into major city districts and a section named Mohammadpur is randomly chosen. Mohammadpur is a city district (locally called a thana) within the Dhaka City Corporation with a population of 355,843 as at the 2011 Census (BBS 2012) and an area of 10.62 square kilometres (Banglapedia n.d.). The author took a rickshaw drive to the Mohammadpur area to explore the slums or clusters of lower socio-economic households and talked to the local shopkeepers, hawkers, rickshaw pullers and other people to get information on the area, and the location of slums etc. Of the slums found in the area, Sona Mia Bosti (Bosti - the Bangla term for 'slum') in Mohammadpur 'Beribadh' (dyke) was picked up to conduct field research because, this slum appeared to be small in size and therefore convenient to get to know better. It also had less developmental intervention.

With an average number of four members in each Jhupi (hut), ${ }^{i}$ Sona Mia slum has an approximate population of 1,400 . The huts are adjacent to each other. There are only 12 tube wells ${ }^{\text {ii }}$ and six toilets to be shared by all slum dwellers, which indicate a serious lack of proper sewage and hygiene. For drinking, bathing and other purposes the residents carry water to their hut from the tube well in buckets. Usually women do this job. Overall, the Sona Mia slum is a typical Dhaka slum, where proper ventilation, drinking water, electricity and sewage facilities are absent, and this absence caused by poverty, leads to further poverty (Alamgir, Jabbar and Islam 2009, p. 75).

Along with the low living standard, Sona Mia slum is characterized by a very low level of development and minimal health facilities. Sona Mia not well attached to metropolitan advantages of life. The mothers interviewed in this slum reported to have known only three sources of maternal health care, namely a maternity centre of Urban Primary Health Care Project (UPHCP, popularly known as Marie Stopesiii), the BRAC Health Centre $(\mathrm{BHC})$ and the Dhaka Medical College Hospital. Maternity centre and BRAC are 
situated near the slum, while the Dhaka Medical College Hospital is some 12 kilometres away. These mothers received maternal health care services mostly from the UPHCP and BRAC health centres. Compared to many other slums, where micro-creditiv and other social development programs contributed better mobility and skills for women (Alamgir, Jabbar and Islam 2009, p. 373), Sona Mia has women who are less mobile and less skilled.

Sona Mia reflects one end of the spectrum of slums in Dhaka in terms of how established they are with infrastructure and services, and what opportunities they offer to their residents to improve their living standards. To better reflect the diversity of slums, another better known slum was added to the study: Karwan Bazar slum, which is located in Tejgaon ${ }^{\vee}$ Thana near one the largest wholesale markets in the central area of Dhaka and the inhabitants seem to be in a slightly better-off economic position.

Karwan Bazar has developed alongside a railway line, close to the bustling business area of Dhaka. The people are living without running water, and work in an unsanitary environment. Similar to Sona Mia, the health and hygiene conditions in the Karwan Bazar settlement, with over 1,000 households, are very poor. However, due to their proximity to the big market, the people living in Karwan Bazar have various income earning opportunities. Compared with the slum dwellers of Sona Mia, those of Karwan Bazar are found to be well networked socially, more informed about available health care, more mobile and have better access to social services. However, their hygiene and housing conditions are similar to that of Sona Mia slum dwellers. A major inconvenience of the Karwan Bazar slum is that its location along a busy railway line, with a daily frequency of around 15-20 trains, weakens the structure of the huts and makes them unsafe to live in. Like the mothers of Sona Mia slum, all of the mothers interviewed in Karwan Bazar also live in rented huts, but their rent is higher because of the locational advantage.

\section{2: Recruitment of key informants and research participants}

As mentioned before the interviews for this study were done with women who had become mothers or prgnant at least once five years preceeding the survey. Because the theme of the study is sensitive and not often spoken about, a variety of sampling procedures have been followed to encourage participation. Table 1 summarizes the sampling procedure that has been followed in recruiting the research participants.

Table 1: Number of participants in this study against each criterion

\begin{tabular}{|l|l|}
\hline Units of research & \multicolumn{2}{|l|}{ Sampling procedure } \\
\hline Study sites & \multirow{2}{*}{ Purposive } \\
\hline Sona Mia Slum & \\
\cline { 1 - 1 } Karwan Bazar Slum \\
\cline { 1 - 1 } Ad-din Women's and Children's Hospital & \\
\cline { 1 - 1 } Urban Primary Health Care Project & \\
Centre & \\
\hline Respondents & \\
\hline
\end{tabular}




\begin{tabular}{|l|l|}
\hline $\begin{array}{l}\text { Respondents from Sona Mia Slum } \\
(n=14)\end{array}$ & Random \\
\hline $\begin{array}{l}\text { Respondents from Karwan Bazar Slum } \\
(n=9)\end{array}$ & Random \\
\hline $\begin{array}{l}\text { Respondents from Ad din Women's } \\
\text { Medical College Hospital }(n=20)\end{array}$ & Accidental \\
\hline $\begin{array}{l}\text { Respondents from Urban Primary } \\
\text { HealthCare Project Centre }(n=5)\end{array}$ & Accidental \\
\hline
\end{tabular}

The sampling frame for the random selection of the eligible mothers was prepared with the help of the dai living in that slum. A lady, named Sheher Banu, who the author met at the entry point of the slum, became a key informant. Sheher Banu runs a tea stall and has good communications with the slum dwellers. She took the author to the hut of a dai who helps with most of the deliveries in the slum. With assistance from the dai, a list of women living in Sona Mia who had given birth in the five years preceding this research field work was done. 14 women from the list were interviewed between 1 August 2012 and 16 September 2012.

For Karwan Bazar, the author spent the first day walking through the slum with the objective of finding a key informant and to be informally oriented with the slum dwellers, and to get information regarding the socio-economic and structural characteristics of the slum. Karwan Bazar is big and sprawling, and not many people know each other. After some informal chats with both men and women to understand their lifestyle and if any of them could be a key informant, a lady named Najma who works in the nearby Urban Primary Health Care Project Office, showed interest in working with as a key informant. She had been living in the slum for more than a decade; held a job, earned money and provided advice and suggestions to the slum dweller women regarding their health problems. With the help of this key informant another walk through the slum was made and informal greetings and smiles with the people (particularly women and children) were exchanged on our way. We did this with the objective of making ourselves familiar to them. With the help of the key informant I also made a list of the women who became pregnant or mothers during the five years preceding or during this research field work. 10 mothers were selected at random from the list to interview.

Of the 48 mothers interviewed in this study, 25 mothers came from different low income areas of Dhaka and its surrounding areas, who were interviewed when they came to receive care and treatment in the Ad-din Women's Medical College Hospital or the Urban Primary Health Care Project Centre in Mohammadpur, Dhaka. The reason for choosing these two health facilities is these two were the most frequently mentioned name of health facililites where mothers from Sona Mia and Karwan Bazar slum went to seek health care.

\section{3: Socio-economic status of mothers: a procreation point of maternal morbidity}

Like several other slums Sona Mia and Karwan Bazar are inhabited by people who migrated to Dhaka predominantly from rural areas of Bangladesh due to a combination 
of push and pull factors. The push factors consist of poverty and related factors and a lack of employment opportunities in the villages, while the pull factors include opportunities for work and better income. However, it was apparent from their living condition that their reasons for migrating to Dhaka for better income and better work opportunities appears not to have been realized as their situation has not improved. The income, economic and social status of the mothers discussed in the following section also depicts this.

\section{1: Income status of the respondents}

Pryer (2003 p. 80) in her study of Dhaka slums found that among the women aged 15 years and above who live in slums, $49 \%$ were engaged in some income generating work. However, in the present study, a much smaller percentage of women are found to be working for an income. The reason is that most of these women have small children to look after at home, as this study selected only those women in the sample who gave birth or became pregnant at least once during the five years preceding the survey.

The daily income of the mothers and the income of their families (which includes the mothers' income) are shown in Table 1 as well as in Figure 1. Although the table and the figure show the same data, the figure has been added for a better visual presentation. The table is useful for calculating measures such as the mean income. The cross tabulation of income of mothers and that of respective families as presented in Table 1 shows that nearly 69\% (33 of 48) of the mothers interviewed had no income, and of those 15 mothers who did have an income, the majority (11) earned only BDT 100 or less per day. The reason for this, as mentioned above is that most of the women interviewed in this study have to look after small children at home. Thus most women interviewed in this study depend on the income of their families (mostly the husbands of these women) which, on average is BDT 305 per dayvi. Figure 1 shows how skewed the individual and family income are towards the lower end of the scale. Beeghley (1988, p. 203) stated that in a cash based society people without jobs are more likely to remain poor. The people living in urban slums can only have income earning activities for their livelihood, unlike those living in rural areas where people can engage in farming, firewood wood gathering etc. for their livelihood. Thus, for the urban poor, being without a job means living in poverty.

\section{Table 1: Distribution of mothers by their own income and family income/day, Dhaka 2012}

\begin{tabular}{|l|l|l|l|l|l|}
\hline $\begin{array}{l}\text { Women's } \\
\text { individual } \\
\text { income } \\
\text { (BDT/day) }\end{array}$ & $\mathbf{1 - 1 0 0}$ & $\mathbf{1 0 1 - 3 0 0}$ & $\mathbf{3 0 1 - 5 0 0}$ & $\mathbf{5 0 1 +}$ & Total \\
\hline No income & 12 & 13 & 5 & 3 & 33 \\
\hline $1-100$ & 0 & 7 & 3 & 1 & 11 \\
\hline $101-300$ & 0 & 2 & 1 & 0 & 3 \\
\hline
\end{tabular}




\begin{tabular}{|l|l|l|l|l|l|}
\hline $501+$ & 0 & 0 & 0 & 1 & 1 \\
\hline Total & 12 & 22 & 9 & 5 & 48 \\
\hline $\begin{array}{l}\text { Mean family income: BDT } \\
\text { members 4 }\end{array}$ &
\end{tabular}

Source: Field work 2012

Figure 1: Distribution of lower soio-economic mothers by their own income and family income

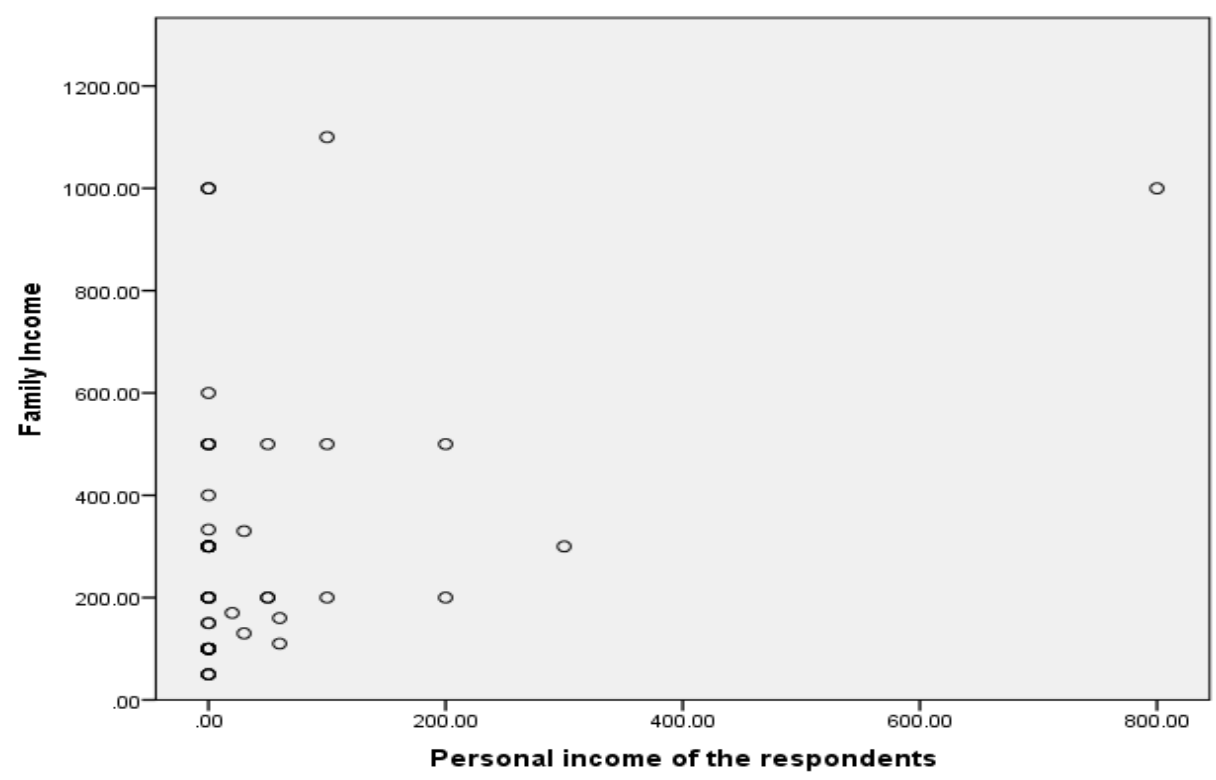

Source: Field work 2012

Table 1 also shows that most of the families (34) have a daily income of BDT 300 or less (USD 3.90 or less). With an average family size of 4 this put them into the category of 'hard core poor'viii (Matin and Hulme, 2003, p. 651), because they all fall below the lower poverty line. Most of the families, where mothers are not earning any income are concentrated in the income range of BDT 300 per day or less (Table 1 and Figure 1). This suggests that if these mothers had an income they could have contributed to improving their family incomes considerably. By having an individual income a woman can have a higher status, which can positively influence her power to make decisions to seek health care for her maternal conditions.

\subsection{2: Employment undertaken by the mothers and their households}

Work available for the mothers and their husbands consists mostly of informal, casual, low skilled, labour intensive and low paid jobs. However, the types of work available in 
Sona Mia and Karwan Bazar slums are different from one another. Being located next to the big Bazar (market places) of Dhaka, inhabitants of the Karwan Bazar slum have opportunities for a variety of work close by. In particular, women and young children from Karwan Bazar slum are able to pick scraps of vegetables and small fish every day from the market shops to supplement their income. Men can earn by selling vegetables, by helping in the shops, or by working as porters. Helena in Karwan Bazar slum describes her family's opportunities for earning some income in the morning, which helps them manage their daily living without having to work all day, as many slum dwellers do:

Researcher: What do your sons do for earning?

Helena: $\quad$ They do whatever they get. This morning my eldest son earned 150 taka, my $2^{\text {nd }}$ son got some fish. I also earned 100 taka in morning.

Researcher: How?

Helena: I bought some vegetables first and then sold it in the nearby area. I made a profit of 100 taka. My eldest son did mintigiri (carrying other people's grocery shopping) in the fish market and earned 150 taka. My $2^{\text {nd }}$ son helped shopkeepers and they gave some fish to him.

Researcher: That's nice! So this is how you earn your daily living?

Helena: $\quad Y e s$, but sometimes we get nothing. My sons also do not like to work every day. They are young, you know. (Helena aged 40 years, Karwan Bazar slum)

On the other hand, Sona Mia slum dwellers, because of the unfavourable location of their slum, have less connection with the markets and work opportunities. The geographical distance of the slum from the city centre has a huge impact on the income earning opportunities for the slum dwellers (Baker 2007, p. 13). However, except for a few, those who work (both male and female), are mostly engaged in low paid casual work and their earnings are below the poverty line income (less than US\$1 a day). The work and economic status of the husbands and families of the women are not different from those of the women themselves. Studies conducted in Dhaka have found that there were 80 different occupations for males living in urban slums of Dhaka (CUS 1983). Most of the household heads in the slums of Dhaka are engaged in low earning informal services like petty business, e.g. footpath vendor, hawker, day labourer, rickshaw puller, labourer in construction buildings, small job service etc. (Alamgir, Jabbar and Islam 2009, p. 375). However, this study did not find such a wide variety of occupations in either Sona Mia or Karwan Bazar slums. Rather, most of the male members of the households interviewed were found to be engaged in informal casual labour work such as pedalling cycle rickshaws (rickshaw puller), assisting truck drivers, selling tea or mineral water bottle, helping in building construction work etc. (see Table 2). In most cases, they do not have regular work due to a lack of availability of regular work, which indicates the prevalent underemploymentix for the poor of Dhaka (Baker 2007, p. 16). Nupur (aged 16 years, mother of one 9 months old child), who has to heavily rely on her own income to run her family, says about her husband,

He cannot earn much because he does not get work every day. He works in brick breaking (ita bhanga). If already enough bricks are broken, he does not get work for the 
next day. If he goes to work, he can earn 100/150 taka per day. He works on an average only 15 days a month. Moreover, he often falls sick.

The occupation of different earning members in households is considered to be one of the determining factors of a household's economic status. As suggested by Table 2 only a few mothers (15 out of a total of 49 respondents) have a regular source of earning money. 
Table 2: Occupation and income/day (in BDT) of the the woman and her husband work, Dhaka, 2012

\begin{tabular}{|c|c|c|c|c|c|c|}
\hline & Name & $\begin{array}{l}\text { Wom } \\
\text { an's } \\
\text { inco } \\
\text { me } \\
\end{array}$ & $\begin{array}{l}\text { Woman's } \\
\text { occupation }\end{array}$ & $\begin{array}{l}\text { Husbands'l } \\
\text { other } \\
\text { family } \\
\text { members' } \\
\text { incomex }\end{array}$ & $\begin{array}{l}\text { Husbands' } \\
\text { occupatio } \\
\text { n }\end{array}$ & $\begin{array}{l}\text { Total } \\
\text { family } \\
\text { income }\end{array}$ \\
\hline \multirow{6}{*}{$\begin{array}{l}\text { Sona } \\
\text { Mia }\end{array}$} & Lailee & 60 & Not specified & 100 & $\begin{array}{l}\text { Rickshaw } \\
\text { puller }\end{array}$ & 160 \\
\hline & Johora & 20 & $\begin{array}{l}\text { Selling fuel } \\
\text { wood }\end{array}$ & 150 & $\begin{array}{l}\text { Rickshaw } \\
\text { puller }\end{array}$ & 170 \\
\hline & Kulsum & 60 & Maid servant & 50 & $\begin{array}{l}\text { Brick } \\
\text { laborer }\end{array}$ & 110 \\
\hline & $\begin{array}{l}\text { Sheher } \\
\text { Banu }\end{array}$ & \multicolumn{4}{|c|}{ Local shop keeper jointly with husband } & 200 \\
\hline & Hena & 50 & Pickle seller & 150 & $\begin{array}{l}\text { Brick } \\
\text { labourer }\end{array}$ & 200 \\
\hline & Khadeja & 50 & Maid servant & 100 & $\begin{array}{l}\text { Ricksha } \\
\text { w puller }\end{array}$ & 150 \\
\hline \multirow{6}{*}{$\begin{array}{l}\text { Karwa } \\
\text { n } \\
\text { Bazar }\end{array}$} & Jhumur & \multicolumn{4}{|c|}{$\begin{array}{l}\text { Grocery shop keeper jointly with } \\
\text { husband }\end{array}$} & 300 \\
\hline & Lolita & 50 & Shop keeper & 450 & $\begin{array}{l}\text { Truck } \\
\text { helper }\end{array}$ & 500 \\
\hline & Feroja & 100 & $\begin{array}{l}\text { Vegetable } \\
\text { seller }\end{array}$ & 400 & $\begin{array}{l}\text { market } \\
\text { labourer }\end{array}$ & 500 \\
\hline & Helena & 100 & $\begin{array}{l}\text { Vegetable } \\
\text { seller }\end{array}$ & 100 & Tea seller & 200 \\
\hline & $\begin{array}{l}\text { Kamrunnah } \\
\text { ar }\end{array}$ & 100 & $\begin{array}{l}\text { Vegetable } \\
\text { seller }\end{array}$ & 1,000 & Food carrier & 1,100 \\
\hline & Selina & \multicolumn{4}{|c|}{ Help mother run hotel } & 1,100 \\
\hline \multirow{3}{*}{$\begin{array}{l}\text { Mother } \\
\text { s in } \\
\text { health } \\
\text { care } \\
\text { facilitie } \\
\text { s }\end{array}$} & Mina & 200 & $\begin{array}{l}\text { Garment } \\
\text { worker }\end{array}$ & 200 & $\begin{array}{l}\text { Garment's } \\
\text { worker }\end{array}$ & 400 \\
\hline & Rahima & 30 & $\begin{array}{l}\text { Garment } \\
\text { worker }\end{array}$ & 330 & Technician & 360 \\
\hline & Karima & 50 & Day laborer & 150 & $\begin{array}{l}\text { Vegetable } \\
\text { seller }\end{array}$ & 200 \\
\hline
\end{tabular}

Note: This table refers to only those households where both the woman and her husband work. There are seven women in Sona Mia and four women in Karwan Bazar and all women except three among those who were interviewed in health facilities, who do not work because of various reasons. Work opportunity and reasons for not working are explained in the following section.

Source: Field work, Dhaka, 2012 


\section{3: Opportunities for work for the mothers}

It has previously been stated that many mothers are not involved in any income earning activities, mainly because they have young children to look after. The other reasons, as reported by the mothers, are the husbands' objection to their wife's work and the mother's own physical illnesses (particularly those who have any kind of maternal morbid condition such as uterine prolapse, fistula etc.). Many mothers cannot be regular in their work due to their physical illness. It is also to be noted that the mothers (mostly from those interviewed at the health care centres), whose husbands manage income through small businesses, are not working. On the other hand, the mothers from the slums, who need to work, cannot do so because they do not get support with childcare. However, those, who have an extended family around and a good social network, can get this support and go to work. As one mother Fatima stated:

All my family members, my brother and sister-in-law, my parents, my sister, all live nearby. I am the poorest of them all. So everyone helps me. When my husband has no income, my parents buy our everyday grocery. They buy rice, daal (lentils) for us. Now I work. I drop my 9-month old daughter at my mother's place in the morning and go to work. I work as a housemaid. Then after finishing my work, I bring my daughter back home. I get 1,800 taka per month. I pay house rent; I have an insurance policy in my daughter's name. I pay for that. I pay for water bill. I spend for family. If my husband gets ill, I pay for his treatment. If my daughter or I am ill, I also spend for our treatment. If I feel like eating something, I buy and eat that. I don't go to others asking for help (Fatima, aged 23 years, mother of one child, from Sona Mia slum).

The above narrative from Fatima, who has been working as a housemaid for the last two months, shows how various kinds of support from the extended family network can help a mother live a better life. In fact, family networks and kinship play an important role in building social capital for the slum dwellers by providing information and adaptation mechanisms (Hossain 2008, p. 20). Other scholars such as Narayan et al. (2000, p. 55) also emphasize the importance of social capital for the poor to meet their everyday needs and to adapt themselves well in the slum community.

Many families in the Sona Mia and Karwan Bazar slums have come to Dhaka recently on their own, leaving their extended family and network back in their villages, and they have not yet been able to build a supporting social or neighbourhood network in their new home. Thus, they neither get any family support to leave their young children with someone to look after them and go for work, nor can they look for suitable work with the help of a network of their own. Saleha, mother of a 9-month old baby, seriously feels the need to work to support her husband, who is often sick. But Saleha can hardly go to work, because she cannot find anyone to look after her child, even though her motherin-law also lives in the same slum. Her situation is reflected in her conversation with me during the interview:

Saleha: $\quad$ But she (her mother-in-law) sleeps in a different hut. She eats with us, but does not help with any of our work.

Researcher: So, you can leave your daughter with your mother-in-law and go to work or for your treatment? 
Saleha: $\quad H m m$. But we only feed them. We don't give any money for her daily living cost. She does some work and earns money and lives with her daughter. She only comes to our hut for her food. My sister-in-law does not eat with us. We are poor. We cannot feed ourselves, how could we feed all of them? (Saleha, aged 20 years, Sona Mia slum)

The difference between Fatima and Saleha in this regard is the support they are receiving from their families. The availability of Fatima's mother to look after her child while Fatima is at work gives her not only the opportunity to earn an income $(1,800$ BDT per month, equivalent to USD 26), but it also gives her self-satisfaction and self-esteem. Her assertion that she can earn and spend as she wishes reflects this. On the other hand, Saleha, having no one to look after her child, is not able to earn and help her husband and herself to alleviate their poverty. The inability of Saleha and her husband to provide full support to her mother-in-law (except for two meals a day) is perhaps the cause of her having a less supportive family network which in turn has led to her continued poverty and even a deteriorating financial situation. Thus Saleha and women like her are caught in a vicious cycle of continuing poverty amid a lack of social and family support, as a support network and kinship in urban informal settlements like the Sona Mia and Karwan Bazar slums play a major role in shaping the socio-economic condition of urban poor mothers.

\section{4: Demographic characteristics of mothers}

The basic demographic features of the respondent mothers are typical of that of Bangladesh in general. Most of the mothers got married and had their first child at a young age.

Table 3: Distribution of the mothers' current and age at first marriage Dhaka, 2012

\begin{tabular}{|l|l|l|l|l|l|}
\hline $\begin{array}{l}\text { Current } \\
\text { age of } \\
\text { mothers }\end{array}$ & $\begin{array}{l}\text { Age at first marriage of the mothers } \\
\text { (years) } \\
\text { Less than } \\
10\end{array}$ & $\begin{array}{l}\mathbf{1 0}- \\
\mathbf{1 4}\end{array}$ & $\mathbf{1 5 - 1 9}$ & $\mathbf{2 0 - 2 4}$ & \\
\hline $10-14$ & 0 & 1 & 0 & 0 & 1 \\
\hline $15-19$ & 0 & 3 & 6 & 0 & 9 \\
\hline $20-24$ & 0 & 5 & 12 & 0 & 17 \\
\hline $25-29$ & 0 & 2 & 0 & 1 & 3 \\
\hline $30-34$ & 2 & 5 & 3 & 0 & 10 \\
\hline $35-39$ & 1 & 1 & 0 & 0 & 2 \\
\hline $40+$ & 2 & 3 & 1 & 0 & 6 \\
\hline Total & 5 & 20 & 22 & 1 & 48 \\
\hline $\begin{array}{l}\text { Current median age: 23.5 years } \\
\text { Median age at marriage: } 14 \text { years } \\
\text { Median age at first childbirth: } 16 \text { years }\end{array}$ \\
\hline
\end{tabular}

Source: Field work 2012 
The current median age of the mothers is 23.5 years. The age range of respondents in this study falls between 15 and 35 years except for five fistula patients, whose age is over 40 years. The cross tabulation presented in Table 3 shows that among the mothers interviewed, 17 fall within the age range 20-24 years followed by 30-34 years in which 10 women belong. The highest number of mothers (22) was married at the age of 15-19 years, followed by 20 mothers who were married at the age of 20 . In particular, of the mothers currently aged 20-24 years, 12 got married at the age of 15-19 years and five at the age of 10-14 years. Although the legal age at marriage for girls in Bangladesh is 18 , the median age of marriage of girls in this study is 14 years. Most of them were married soon after they reached puberty, which is the general scenario of marriage age of girls in Bangladesh. The mean age at marriage of girls in Bangladesh is 15 years (NIPORT et al. 2011, p. 87).

As a consequence of early marriage, the mothers give birth at a young age. The median age at first childbirth of the mothers is 16 years, which is far below the median age of first childbirth in Bangladesh overall, which is 18.1 years (NIPORT et al. 2011, p. 70). Early marriage is associated with early age at first childbirth, often before the mothers physical growth and development is complete. Many studies have shown that early childbirth can have adverse health consequences for both the woman and the child (Jensen 2003, p. 10; Field 2008, p.2). Wall (2006, p. 1,206) concisely presents the impact of early marriage and early child bearing on the health of mothers

The likelihood of obstructed labour is increased in areas where early marriage and childbearing are common, because although growth in height stops or slows with the onset of menarche ${ }^{\text {xii }}$, the capacity of the bony pelvis normally continues to expand after the epiphysis ${ }^{x i i i}$ growth plates of the long bones have fused. These problems are worsened if girls have been undernourished throughout childhood and adolescence. Thus, although girls are capable of becoming pregnant at a relatively early age, their pelvis do not develop their full capacity to accommodate childbearing until much later, and many will have their lives destroyed by obstetric injury before they have even crossed the threshold into true adulthood.

In Bangladesh, early age at marriage and early age at first childbirth are recognized as major factors in maternal death and maternal morbidity. Available data show that one of the reasons for the high level maternal mortality ratio (MMR) in Bangladesh is the large proportion of adolescent mothers. The MMR among adolescent mothers is $30-50 \%$ higher than the overall MMR in Bangladesh (GOB and UN 2005).

To sum up, the socio-economic and demographic background of mothers is typical of urban poor households of Bangladesh. The income of these mothers and their families is generated from informal, casual, low skilled jobs and ranges between BDT 100 and 300 per day, which is below the poverty line. The work opportunities of these mothers are also limited due to the unavailability of regular work and lack of family support in looking after the children of the mothers who do find work. Their situation is made worse when they suffer from illness. These limitations contribute to their poverty. Their living conditions are very poor, particularly in terms of access to, and affordability of utilities, sewage disposal and overall hygiene. Further, being adjacent to a railway line, the living condition of the mothers in Karwan Bazar is even worse and unsafe. In terms of demographic characteristics; the average current age of mothers is 26 years. 
On the other hand, the mothers who were interviewed at the health facilities namely Addin and maternity centre of UPHCP, Dhaka have a regular family income which helps them to plan well for facility based health care during pregnancy, delivery and the postdelivery period.

\section{4: Maternal health care behaviour of mothers}

Many mothers of were found to have received inadequate health care during their pregnancy, childbirth and post-partum period. Lack of child delivery care and postdelivery care, coupled with poor nutritional status and early child bearing have left many of them with maternal illnesses such as fistula, uterine prolapse, urinary incontinence, chronic backache etc. This section focuses particularly on:

- Health care status of the mothers in terms of their ante natal, delivery and postpartum care.

- The type and duration of delivery complication and post-partum delivery morbidity of the mothers, and

- The reasons, as understood by the mothers, and the consequences of maternal morbidity.

\subsection{1: Maternal health care status of mothers}

The type, number and quality of maternal health care received by the mothers during pregnancy, delivery and the post-partum period determines their short term and long term morbidity status (McCarthy and Maine, 1992, p. 33). According to the Safe Motherhood Initiative, the provision of ante-natal care, access to emergency obstetric care (EOC), ensuring skilled birth attendants and education and mobilization of the community are significant components to ensure healthy pregnancy outcomes for mother (McCarthy and Maine 1992, p. 30). In this section, ante-natal care, delivery care and post-partum care of the mothers is presented. 
Table 4: Health care status of the mothers, Dhaka 2012

\begin{tabular}{|c|c|c|c|c|c|c|c|}
\hline \multirow{2}{*}{$\begin{array}{l}\text { Place of } \\
\text { residence and } \\
\text { the numbers of } \\
\text { mothers } \\
\text { interviewed }\end{array}$} & \multicolumn{2}{|c|}{$\begin{array}{l}\text { ANC } \\
\text { (Yes/No) }\end{array}$} & \multicolumn{2}{|c|}{$\begin{array}{l}\text { Place of } \\
\text { delivery }\end{array}$} & \multicolumn{2}{|c|}{$\begin{array}{l}\text { Type of } \\
\text { delivery }\end{array}$} & \multirow{2}{*}{$\begin{array}{l}\text { Morbidity* } \\
\text { No morbidity (6) }\end{array}$} \\
\hline & Yes & No & $\begin{array}{l}\text { Hom } \\
\text { e }\end{array}$ & $\begin{array}{l}\text { Hospit } \\
\text { al }\end{array}$ & CS & $\begin{array}{l}\text { Norma } \\
1\end{array}$ & \\
\hline \multirow[t]{3}{*}{$\begin{array}{l}\text { Sona Mia slum } \\
\text { (14) }\end{array}$} & \multirow[t]{3}{*}{11} & \multirow[t]{3}{*}{4} & \multirow[t]{3}{*}{12} & \multirow[t]{3}{*}{2} & \multirow[t]{3}{*}{1} & \multirow[t]{3}{*}{13} & $\begin{array}{l}\text { Delivery complication } \\
\text { 4) }\end{array}$ \\
\hline & & & & & & & $\begin{array}{l}\text { Post-partum } \\
\text { morbidity (8) }\end{array}$ \\
\hline & & & & & & & No morbidity (4) \\
\hline \multirow[t]{3}{*}{$\begin{array}{l}\text { Karwan Bazar } \\
\text { slum (10) }\end{array}$} & \multirow[b]{3}{*}{4} & \multirow[b]{3}{*}{6} & \multirow[b]{3}{*}{7} & \multirow[b]{3}{*}{3} & \multirow[b]{3}{*}{1} & \multirow[b]{3}{*}{9} & $\begin{array}{l}\text { Delivery complication } \\
\text { (4) }\end{array}$ \\
\hline & & & & & & & $\begin{array}{l}\text { Post-partum } \\
\text { morbidity (6) }\end{array}$ \\
\hline & & & & & & & No morbidity (7) \\
\hline \multirow{2}{*}{$\begin{array}{l}\text { Interviewed at } \\
\text { health care } \\
\text { centres (13) }\end{array}$} & \multirow[b]{2}{*}{13} & \multirow[b]{2}{*}{0} & \multirow[b]{2}{*}{13} & \multirow[b]{2}{*}{0} & \multirow[b]{2}{*}{6} & \multirow[b]{2}{*}{7} & $\begin{array}{l}\text { Delivery } \\
\text { complication (8) }\end{array}$ \\
\hline & & & & & & & $\begin{array}{l}\text { Post-partum } \\
\text { morbidity (2) }\end{array}$ \\
\hline \multirow{2}{*}{$\begin{array}{l}\text { Mothers } \\
\text { affected by } \\
\text { obstetric fistula } \\
\text { (11) }\end{array}$} & \multirow[t]{2}{*}{0} & \multirow[t]{2}{*}{11} & \multirow[t]{2}{*}{5} & \multirow[t]{2}{*}{6} & \multirow[t]{2}{*}{2} & \multirow[t]{2}{*}{9} & $\begin{array}{l}\text { Delivery } \\
\text { complication (11) }\end{array}$ \\
\hline & & & & & & & $\begin{array}{l}\text { Post-partum } \\
\text { morbidity (11) }\end{array}$ \\
\hline
\end{tabular}

*The numbers presented in this column are not mutually exclusive, as some mothers had morbid conditions during child delivery as well as after childbirth.

Source: Field work, 2012

Among the total 48 mothers, 17 reported not to have had any morbidity or illness (Table 4). These 17 comprise six mothers from Sona Mia slum, four from Karwan Bazar and seven interviewed at health care centres. The seven mothers, who came to the health centres in spite of having had no existing morbidity, chose to come to the health facilities for child delivery. The remaining 31 mothers suffered various complications, either at childbirth or during the postpartum period. Many of them had more than one type of complication. Each of these mothers narrated her unique experience with regards to her complication, illness, duration of illness and treatment of illness. The morbidities or illnesses reported by them consist of uterine prolapse (locally known as 'Poddo', which is resemblance of the lotus flower), chronic back pain, urinary incontinence, anaemia and fistula. These conditions are the outcomes of complications such as prolonged labour, frequent pregnancies, early age pregnancy, inadequate and delayed obstetric care and carrying heavy weights during pregnancy. All of these may be linked to whether the women are receiving proper, timely and adequate health care during their pregnancy and delivery. Table 4 also gives the number of mothers according to whether they had ante-natal care (ANC), care during delivery and post- 
delivery care. The information presented in this section focuses generally on the most recent pregnancy of those mothers who became pregnant in the five years preceding this survey.

Compared with other components (delivery care and post-partum care), ante-natal care (ANC) was more prevalent among the mothers (Table 4). However, in most cases, the mothers reported at interviews that their ANC visits were limited only to receiving tetanus toxoid (TT) injections and for a few mothers, to receive iron-vitamin tablets. The other elements of ante-natal care such as measuring blood pressure, urine tests, measuring weight, or blood tests (NIPORT 2012, p. 55) were done for a very few mothers interviewed. The reason for this could be what is mentioned in the report on the Bangladesh Maternal Mortality and Health Care Survey by NIPORT et.al. (2012, p. 53), namely that women with a lower educational attainment are less likely to be advised to get their weight monitored during pregnancy or have their blood pressure, urine and blood tested. Perhaps the health care providers were apathetic towards these lowly educated women who felt that they could not demand such tests.

In other words, the mothers living in the poor socio-economic households received mostly those services which came to their door step. In Sona Mia slum, health workers from the nearby UPHCP came twice a week to provide injections and vitamin-iron tablets to pregnant women. A very similar experience is shared by the mothers living in Karwan Bazar slum, where they received ante-natal care from the nearby 'Surjer Hasi' (literally meaning Smiles of the Sun) clinic. However, while in many cases they were advised to go for an ultra sound or blood test, they could not afford to do so due to various reasons stated by the mothers. In the words of Rehana:

Apa I won't tell a lie. I did not go anywhere. People suggested me to go for a check-up, especially for injections. But I did not go. I am scared of injections. People said, if you do not go for injections, you might have trouble afterwards. But I did not care, because I do not trust them. I was confused whether they are telling me the truth or a lie (Rehana, aged 16, mother of one child, Sona Mia slum).

On the other hand, in addition to receiving a tetanus toxoid injection during her pregnancy, Taslima from Sona Mia slum managed to go for an ultrasound test in the fifth month of her pregnancy with help of neighbours. Although both Rehana and Taslima are poor, and without any income or a job, the difference between their situation is that Taslima has been living in Dhaka for quite a few years and has built up a neighbourhood network that she can rely on. On the other hand, Rehana migrated to Dhaka only six months ago and has not yet been able to develop a trust worthy neighbourhood network. The mothers, whom I interviewed at health facilities, took antenatal care (ANC) seriously and follow the advice of their health providers.

Compared with ANC, the quantity and quality of childbirth care obtained by the mothers is low. Among 23 mothers from the two slums only five had their children delivered at health care centres (Table 4). Of the 23 women interviewed at the Ad-din Hospital and the maternity centre, 12 women had their delivery at a hospital. However, hospital based delivery in all these cases does not mean that they all chose to have a hospital based childbirth had a normal delivery. Rather, these women who went to the hospital for their delivery were taken there in the last stages of prolonged labour or obstructed 
labour which eventually resulted in conditions like obstetric fistula or uterine prolapse. It is seen in the Three Delay Model of Thaddeus and Maine (1994) how delays in transferring women with obstetric complications to hospitals cause maternal death or morbidity.

The importance of post-partum care in preventing maternal morbidity and maternal mortality is indisputable as post-partum complication mostly occurs during the 24 hours following a delivery (NIPORT et al. 2013, p. 132). However, similar to the low prevalence of post-partum care in Bangladesh as a whole, where only $27 \%$ of mothers are reported to have received post-partum care for themselves (NIPORT et al. 2013, p. 133), the mothers in this study also have a very poor response to post-partum care (PNC). None of the mothers, who had a home based childbirth, went to receive PNC anywhere. Those, who did have a PNC reported at the interview that they actually had hospital based childbirth and went for a routine PNC visit. The lack of PNC visits is more likely to increase the chance of post-partum maternal morbidity. The following section elaborates on the causes of and suffering from the maternal morbidity as reported by the mothers. 


\section{5: The causes of morbidity and suffering of affected mothers}

Uterine prolapse, obstetric fistula, urinary incontinence, perennial tears and chronic backache were found to be the major morbidity incidents among the mothers. The average duration of suffering varies between two and seven years (Table 5). The duration of suffering is the period that a woman has been suffering from a condition since its onset. All the mothers interviewed who were suffering from fistula had sought treatment for their illness. It is important to note however, that not every mother suffering from fistula is receiving treatment. Rather it means that in this research, only those fistula affected mothers, who were receiving treatment at the health facilities. Before coming to the health centre, they remained untreated for a long time since developing obstetric fistula. Some of the respondents reported as having more than one morbidity. In particular those having prolapsed uterus also had urinary incontinence, chronic backache etc. As Bonetti et al. (2004, p. 167) discussed, maternal morbidities like uterine prolapse can cause other conditions like lower back pain and put mothers in a very uncomfortable situation to do their daily work.

Table 5: Types and duration of morbidity among the mothers, Dhaka, 2012

\begin{tabular}{|c|c|c|c|c|}
\hline \multirow[t]{2}{*}{$\begin{array}{l}\text { Type of morbidity/ } \\
\text { complication }\end{array}$} & \multirow[t]{2}{*}{$\begin{array}{l}\text { Number of } \\
\text { respondents* }\end{array}$} & \multirow{2}{*}{$\begin{array}{l}\text { Average duration } \\
\text { of suffering in } \\
\text { years }\end{array}$} & \multicolumn{2}{|c|}{$\begin{array}{l}\text { Treatment } \\
\text { sought }\end{array}$} \\
\hline & & & Yes & No \\
\hline Fistula & 10 & 7 & 10 & 0 \\
\hline Uterine prolapsed & 10 & 4 & 3 & 7 \\
\hline $\begin{array}{l}\text { Urinary } \\
\text { incontinence }\end{array}$ & 3 & 2 & 0 & 3 \\
\hline Perennial tears & 9 & 2 & 0 & 9 \\
\hline $\begin{array}{l}\text { Anaemia/weaknes } \\
\mathrm{s}\end{array}$ & 15 & 4 & 3 & 12 \\
\hline Chronic back pain & 9 & 4 & 2 & 7 \\
\hline
\end{tabular}

Source: Field work 2012

*Some respondents reported multiple complications

Among all morbidity conditions suffered by women, fistula is the worst in terms of duration and the nature of suffering (Ahmed and Holtz 2007, p. S10; Bangser 2006, p. 535; Muleta 2006, p. 963; UNFPA 2003, p. 13; Roush et al. 2012, p. 787). The sensitivities surrounding the treatment of fistula as well as the costs involved make the sufferer endure the pain and suffering for very long periods. As shown in Table 4.5, the duration of suffering from fistula is also found to be longer than that for other maternal illnesses. The reason for this long duration for fistula could be many, and would include lack of information on and access to, fistula treatment, and insufficient financial ability to treat fistula.

The reasons for maternal morbidity conditions for mothers are mostly related to their poverty. Early age at marriage, frequent child bearing with high parity, heavy work in household chores during and after delivery, mishandling of vaginal delivery by TBA, under-nutrition, anaemia and socio-economic factors that inhibit timely or any 
healthcare seeking are considered to be the main reasons for morbidities such as uterine prolapse, urinary incontinence and/or chronic backache. Previous studies conducted elsewhere (Walker et al. 2011, p. 129; Bonetti et al. 2004, p. 169) have come up with similar findings. Overall, the failure to receive timely and skilled delivery care and post-partum care as well as lack of support with household work after childbirth are other factors which exacerbate these mothers' susceptibility to post-partum morbid conditions.

The post-partum morbidity conditions have serious consequences for these women's lives and their suffering is intense. Their daily life, their work and their relationships with their husbands are badly affected (Bonetti, Erpelding and Pathak 2004, p.167). For example, women with uterine prolapse suffer from abdominal pain, chronic backache, painful intercourse, white watery discharge, a burning during urination and difficulty in lifting, sitting and standing (Bodner-Adler 2007, p. 1,345). Mothers of lower who suffer from maternal morbidity reported various kinds of physical and emotional pain and suffering, as shown in Table 6.

Table 6: Pain and suffering due to maternal morbidity among mothers, Dhaka, 2012

\begin{tabular}{|ll|}
\hline Physical pain & $\begin{array}{l}\text { Difficulties in doing regular work at home and } \\
\text { outside } \\
\text { Continuous physical discomfort } \\
\text { Pain and burning }\end{array}$ \\
$\begin{array}{l}\text { Mental and social } \\
\text { stress/fear }\end{array}$ & $\begin{array}{l}\text { Fear of being abandoned by the husband } \\
\text { Economic } \\
\text { vulnerability }\end{array}$ \\
& $\begin{array}{l}\text { Lental stress due to not being able to work } \\
\text { Loosing honour in society } \\
\end{array}$ \\
& $\begin{array}{l}\text { Stigmatized by the neighbourhood } \\
\text { Loss or discontinuity of earning due to loss of } \\
\text { physical capability to work }\end{array}$ \\
\hline
\end{tabular}

Source: Field work 2012

Any illness causes pain and suffering to the person having that illness, but the duration and intensity of suffering varies according to the particular type of condition or illness. Further, the pain and suffering may not only be physical, but may also cause mental stress and render a person socio-economically vulnerable as well. For example, morbidity such as urinary incontinence and perennial tears cause burning sensation during urination and intercourse.

As stated by Laili from Sona Mia slum, who is aged 25 years and mother of two children:

I can't go out in the sun. Amar matha ghuray (I feel dizzy). Moreover, when I urinate, it burns. Sometimes I stay well, but most of the time it burns so much that I can't even urinate properly and later my clothes gets dirty. My Tolpet (lower abdomen) becomes 
sore a lot. It's been three to four years since I have this problem (Laili, aged 23 years, mother of two children).

Uterine prolapse (locally known as poddo), if it happens at an advanced stage, creates problems for women doing households chores. Many mothers interviewed in this study work as housemaids to earn their living. This work requires them to sit down in a squatting position for long hours to mop floors, wash clothes and cut up vegetables etc. Squatting makes their prolapse worse. Moreover, women suffering from this illness cannot do their work efficiently. Nupur (aged 22 years) from Sona Mia slum, who has uterine prolapse, described her condition as follows:

Now my only problem is that 'poddo' comes out and hurts me when I sexually interact with my husband and do my household chores.

This physical suffering from a maternal morbidity has important social dimensions, including social suffering, and being abandoned or exploited by husbands. Particularly, mothers suffering from fistula, in many cases, have been abandoned by their husbands, secluded and stigmatized. As found in this study, mothers suffering from maternal morbidity, such as uterine prolapse, anaemia and backache always fear being abandoned by their husband or fear being labelled as 'unproductive' by the society. Rehana, Hasna, Banu and Rumu from Sona Mia slum and Lotita from Karwan Bazar slum expressed their concern that their husbands will abandon them if they are not capable enough to satisfy the needs of household work and those of sexual and reproductive life. Stanton and Brandes (2012, p. 122) summarize the social consequence of maternal morbidity, particularly in the case of mothers suffering from uterine prolapse in Bangladesh, as follows:

[W]omen with conditions of chronic maternal morbidities, such as uterine prolapse, sometimes experience khota (insult) whereby they are ridiculed by neighbours and inlaws for jeopardizing the marriage through not meeting the sexual needs of the husband or not carrying out household responsibilities.

Stanton and Brandes (2012) also showed in their research that the economic consequences of maternal morbidity are intense at the beginning of the onset of a complication, i.e. the first six weeks after birth and then the consequences tend to diminish. This might be due to fact that the poor family has to take out a loan to treat the maternal complication as soon as it is detected. In this current study, it was found that Rumu and Reshma both had to take out a large loan from their neighbours to go to a hospital and receive treatment for obstetric complications. Rumu got these conditions three years ago and although she has now recovered she is still carrying the debt and working hard to repay the same. Reshma, who had been suffering from post-delivery complications and anaemia for the six months preceding the field work, is still carrying the debt which she incurred during her treatment but she cannot yet return to work to repay her debt. So, in some cases the economic consequences of a maternal illness last longer than other consequences. The long term economic consequence of maternal morbidity was also evident particularly for those women who used to work regularly to earn money as garment workers or housemaids. Conditions like uterine prolapse, urinary incontinence, and backache gives them intense physical suffering and makes them unable to work. 
The intensity of suffering eventually makes the women very keen to treat their illness. Ironically however, they have a dearth of information about the availability of, and opportunities for appropriate treatment. In addition, they experience economic, social, familial and structural barriers to receiving treatment. As a result, their suffering gets more serious and lasts longer.

\section{6: Conclusion}

As derived from the above discussion, the residence, income and employment status, pattern of current age, age at marriage and first childbirth, and the type of maternal health care the mothers received during pregnancy and childbirth altogether present a precarious condition in which mothers live in. The mothers in this study come from a typical poverty situation of very low income, low education, poor housing, poor hygiene and poor health status. According to the World Health Organization, this kind of "[p]overty is associated with the undermining of a range of key human attributes, including health" (WHO n.d.). They are poor in terms of continuous deprivation of what they need. Deepa Narayan (2000, p. 56) explains this poverty as "a combination of issues where people might suffer from shifting combinations of problems over time". The women here are poor not only because they come from poor households, but also because they are deprived of many things and services that they are entitled to access and receive legally and socially. They experience poor maternal health because they enter into motherhood with poor nutrition and poor health status; they do not receive proper medical care during their maternal morbidity and complications because they are not informed and educated enough about this. Winikoff (1988) similarly addressed how ill health is perpetuated from mothers to children. A girl child growing up in a resource constrained environment with a reduced share of food, health, education and other household and social resources turned into a bride as soon as (or even before) she reaches puberty has to give birth to a child at early age without 'reliable' and 'adequate' care during pregnancy and childbirth (Winikoff 1988, pp. 197-198). Thus, their poverty experience has multifaceted dimensions that need to be addressed comprehensively to understand their health care seeking behaviour.

That is why, in this study, poverty of the participant mothers and their households should be seen not only from the perspective of lack of money, but it should also be seen from the perspective of numerous non-monetary factors, for example, factors underlying the social, structural and cultural setting, influence the health care seeking behaviour of mothers for their child delivery and post-partum care in poor socioeconomic settings. In fact, as Ruth (2004, p. 16) argued the capability of someone to do something is only partly explained by money or in others words what money buys is merely a "means" to the way "of achieving the functioning". Sen (1979, p. 271) argued that the functioning of achieving something largely depends on the social arrangement (Sen 2008, 273) in which s/he lives plus her/his personal characteristics. 
In the urban context, where health care facilities are mostly in close proximity of the mothers, the reason for their inadequate health care for childbirth and post-partum care may lie in the socio-cultural atmosphere of the urban slum the mothers live in e.g., social network, availability of information, support network from family and neighbourhood etc. as well as the 'personal characteristics' of mothers like education, age and self-esteem. Together, the social arrangements and personal characteristics may hinder mothers from being 'capable' enough to achieve the optimum 'functioning' by using their limited resources and money. And this leads to morbidity conditions during and after delivery. Many women end up having short term and/or long term maternal morbidity or illnesses. The socio-economic status of the respondents often comes forward as the main determinants for a mother whether to seek or not to seek health care for maternal morbidity.

i Jupri is a kind of house made of low cost housing materials like tin, bamboo, straw and polythene and becomes vulnerable during the rainy season (Hossain 2008, p. 18).

ii A tube well is a well made by driving a tube into the earth that draws water from the underground aquifer (Smith, Lingas and Rahman_2000, p. 1,093). In Bangladesh, tube wells are used as a source of drinking water.

iii This Urban Primary Health care Project Centre is supported by Marie Stopes International. That is why; people call this centre as Marie Stopes.

iv Small amount of collateral free institutional loan, usually provided to the poor group member with a view to develop self- reliance and income generation among them (Rahman 1999, p. 67).

$\checkmark$ Tejgaon is a Thana (city district), located at the centre place of Dhaka.

vi BDT stands for Bangladeshi Taka. 1 USD equals approximately 75 BDT.

vii Family income refers to income of all earning members of the family of responded mother including her own income.

viii "The conceptualization behind the hard core poor is that they experience extreme poverty and that, because of their lack of opportunities for upward mobility, their poverty lasts a long time or throughout their entire life" (Matin and Hulme 2003, p. 651).

ix "The conceptualization behind the hard core poor is that they experience extreme poverty and that, because of their lack of opportunities for upward mobility, their poverty lasts a long time or throughout their entire life" (Matin and Hulme 2003, p. 651).

x Family income includes husband's income and wife's income, in cases where wife earns money.

xi This is the median age at marriage of the married women in this sample.

xii First menstrual cycle 


\section{References:}

Afsana, K \& Wahid, SS 2013, 'Health care for poor people in the urban slums of Bangladesh', The Lancet, vol. 382, no. 9910, pp. 2049-051.

Ahmed, S, \& Holtz, SA 2007, 'Social and economic consequences of obstetric fistula: Life changed forever?', International Journal of Gynecology \& Obstetrics, vol. 99, pp. S10-S15.

Alamgir, MS, Jabbar, MA. \& Islam, MS 2009,'Assessing the livelihood of slum dwellers in Dhaka city', Journal of the Bangladesh Agricultural University, vol. 7, no. 2, pp. 373-80.

Ashford, L 2002, 'Hidden Suffering: Disabilities from Pregnancy and Childbirth in Less Developed Countries', Population Reference Bureau, viewed 6 February 2015, http://www.prb.org/Publications/PolicyBriefs/HiddenSufferingDisabilitiesFromPregnancyandChildbirt hinLDCs.aspx

Baker, JL 2007, 'Dhaka: Improving Living Conditions for the Urban Poor'. Bangladesh Development Series 17, World Bank, Washington, DC.

Bangladesh Bureau of Statistics (BBS) 2011, Bangladesh population and housing census 2011, Ministry of Planning, Dhaka.

Bangser, M 2006, 'Obstetric fistula and stigma', The Lancet, vol. 367, no. 9509, pp. 535-36.

Begum, HA, Yeasmin, NN, Sayem, AM 2010, 'Utilization of Maternal Health Care Services in Slum Areas of Dhaka city, Bangladesh', Ibrahim Medical College Journal, vol. 4, no, 2, pp. 44-48.

Beeghley, L 1988, 'Individual and Structural Explanation of Poverty', Population Research and Policy Review, vol.7, no. 3, pp. 201-22.

Bodner-Adler, B, Shrivastava, C, \& Bodner, K 200, 'Risk factors for uterine prolapse in Nepal', International Urogynecology Journal, vol. 18, no. 11, pp. 1343-346

Bonetti, TR, Erpelding, A \& Pathak, LR 2004, 'Listening to "felt needs": investigating genital prolapse in western Nepal', Reproductive health matters, vol. 12, no. 23. pp. 166-75.

Centre for Urban Studies (CUS) 1982, Slums in Dhaka City: A socio-economic survey for Feasibility of Slums Clearance and Urban Renewal Program in Dhaka City, Centre for Urban Studies, Dhaka.

Field, E \& Ambrus, A 2008, 'Early marriage, age of menarche, and female schooling attainment in Bangladesh', Journal of Political Economy, vol. 116, no. 5, pp. 881-30.

Filippi, V, Ronsmans, C, Campbell, OM, Graham, WJ et. al. 2006, 'Maternal health in poor countries: the broader context and a call for action', The Lancet, vol. 368, no.9546, pp. 1535-541.

Firoz, T, Chou, D, Von Dadelszen, P, Agrawal, P, et. al. 2013, 'Measuring maternal health: focus on maternal morbidity', Bulletin of the World Health Organization, vol. 91, no. 10, pp.794- 96.

Glazener, C, Abdalla, M, Stroud, P, Templeton, A. 1995, 'Postnatal maternal morbidity: extent, causes, prevention and treatment', BJOG: An International Journal of Obstetrics \& Gynaecology, vol. 102, no. 4 , pp. 282-87.

Government of Bangladesh \& United Nations Country Team in Bangladesh 2005, 'Millennium Development Goals: Bangladesh Progress Report', viewed 6 February 2015, http://www.undg.org/archive docs/5580-Bangladesh MDG Report.pdf

Goodburn, EA, Gazi, R \& Chowdhury, M 1995, 'Beliefs and Practices Regarding Delivery and Postpartum Maternal Morbidity in Rural Bangladesh', Studies in Family Planning, vol. 26, no. 1, pp. 22-32.

Hossain, S 2008, 'Rapid Urban Growth and Poverty in Dhaka City', Bangladesh e-Journal of Sociology, vol.5, no. 1, pp. 1-28, viewed 24 November 2013 http://www.bangladeshsociology.org/

Human Development Research Centre 2011, Study on allocation, targeting and effectiveness of sanitation subsidy in Bangladesh, Report prepared for WaterAid Bangladesh, Bangladesh. 
Jensen, R \& Thornton, R 2003, 'Early female marriage in the developing world', Gender \& Development, vol. 11, no. 2, pp. 9-19.

Lewis, G 2003, 'Beyond the numbers: reviewing maternal deaths and complications to make pregnancy safer', British Medical Bulletin, vol. 67, no. 1, pp. 27-37.

Matin, I \& Hulme, D 2003, 'Programs for the Poorest: Learning from the IGVGD Program in Bangladesh', World Development, vol. 31, no. 3, pp. 647-65.

McCarthy, J \& Maine, D 1992, 'A Framework for Analyzing the Determinants of Maternal Mortality', Studies in Family Planning, vol. 23, no. 1, pp. 23-33.

Muleta, M 2006, 'Obstetric fistula in developing countries: a review article', Journal of obstetrics and gynaecology Canada: JOGC= Journal d'obstétrique et gynécologie du Canada: JOGC, vol. 28, no. 11 , pp. 962-66.

Narayan, D, 2000, Voices of the Poor: Can Anyone Hear Us, Oxford University Press, New York.

National Institute of Population Research and Training (NIPORT), Mitra and Associates, and ICF International. 2013, Bangladesh Demographic and Health Survey 2011, Dhaka, Bangladesh and Calverton, Maryland, USA: NIPORT, Mitra and Associates and ICF International.

National Institute of Population Research and Training (NIPORT), MEASURE Evaluation, and ICDDR,B. 2012, Bangladesh Maternal Mortality and Health Care Survey 2010. Dhaka, Bangladesh: NIPORT, MEASURE Evaluation, and ICDDR,B.

National Institute of Population Research and Training (NIPORT), MEASURE Evaluation, International Centre for Diarrhoeal Disease Research, Bangladesh (ICDDR,B), and Associates for Community and Population Research (ACPR), 2006 Bangladesh Urban Health Survey. Dhaka, Bangladesh and Chapel Hill, NC, USA: NIPORT, MEASURE Evaluation, ICDDR,B, and ACPR; 2008. ISBN: 978-0-9842585-7-4,

Oakley, A 1984, The captured womb: A history of the medical care of pregnant women, Blackwell Oxford.

Pryer, J 2003, Poverty and Vulnerability in Dhaka Slums: The Urban Livelihoods Study, Ashgate Publishing, Limited, Aldershot

Rahman, A 1999, 'Micro-credit initiatives for equitable and sustainable development: Who pays?', World development, vol. 27, no. 1, pp. 67-82.

Reed, H, Koblinsky, M \& Mosley, HW (Eds.) 2000, The consequences of maternal mortality and maternal morbidity: report of a workshop, National Academy Press, Washington DC.

Rothman, BK, 1982, In labor: Women and power in the birthplace, Norton New York.

Roush, K, Kurth, A, Hutchinson, MK \& Van Devanter, N 2012, 'Obstetric fistula: what about gender power?', Health care for women international, vol. 33, no. 9, pp. 787-98.

Sen, A, 2008, 'Capability and well-being', in DM Hausman (ed.), The Philosophy of Economics: An Anthology, Cambridge University Press, Cambridge.

Shaikh, BT \& Hatcher, J, 2005, 'Health seeking behaviour and health service utilization in Pakistan: challenging the policy makers', Journal of public health, vol. 27, pp. 49-54.

Sharma, SK, Sawangdee, Y \& Sirirassamee, B 2007, 'Access to health: women's status and utilization of maternal health services in Nepal', Journal of Biosocial Science, vol. 39, pp. 671-92.

Siddiqui, K. 2000. Overcoming the governance crisis in Dhaka City, University Press, Limited.

Stacey, M 1994, The power of lay knowledge, in J, Popay \& G, Williams (eds), Researching the People's Health, pp.85-98, London: Routledge.

Stanton, ME \& Brandes, N 2012, 'A new perspective on maternal ill-health and its consequences', Journal of health, population, and nutrition, vol. 30, no. 2, pp.121-23. 
Thaddeus, S \& Maine, D 1994, 'Too far to walk: Maternal mortality in context', Social Science \& Medicine, vol. 38, no. 8, pp. 1091-110

UNFPA 2003, South Asia conference for the prevention \& treatment of obstetric fistula, Dhaka, Bangladesh, 9-11 Dec 2003, http://www.unfpa.org/publications/south-asia-conference-preventionand-treatment-obstetric-fistula

Walker, GJ \& Gunasekera, AP 2011 'Pelvic organ prolapse and incontinence in developing countries: review of prevalence and risk factors', International urogynecology journal, vol. 22, no.2, pp. 12735.

Wall, LL 2006, 'Obstetric vesicovaginal fistula as an international public-health problem', The Lancet, vol. 368, no. 9542, pp. 1201-209.

Winikoff, B 1988, 'Women's health: an alternative perspective for choosing interventions', Studies in Family Planning, vol. 19, no. 4, pp. 197-213.

World Health Orgnazation n.d. Poverty, viewed 5 May 2013, http://www.who.int/topics/poverty/en/ 